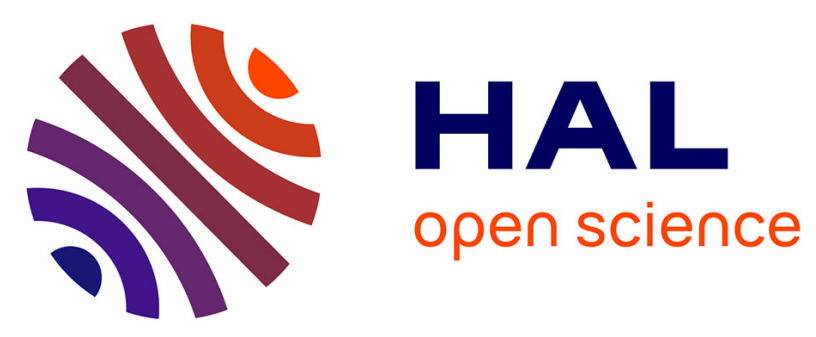

\title{
Quantification of Volatile Organic Compounds Diffusion for Virgin Geosynthetic Clay Liners and for a GCL after Contact with a Synthetic Leachate
}

\author{
S. Rosin-Paumier, N. Touze-Foltz, L. Mazéas, A. Guenne
}

\section{- To cite this version:}

S. Rosin-Paumier, N. Touze-Foltz, L. Mazéas, A. Guenne. Quantification of Volatile Organic Compounds Diffusion for Virgin Geosynthetic Clay Liners and for a GCL after Contact with a Synthetic Leachate. Journal of Geotechnical and Geoenvironmental Engineering, 2011, 137 (11), pp.1039 - 1046. 10.1061/(ASCE)GT.1943-5606.0000525 . hal-01717748

\author{
HAL Id: hal-01717748 \\ https://hal.science/hal-01717748
}

Submitted on 15 May 2020

HAL is a multi-disciplinary open access archive for the deposit and dissemination of scientific research documents, whether they are published or not. The documents may come from teaching and research institutions in France or abroad, or from public or private research centers.
L'archive ouverte pluridisciplinaire HAL, est destinée au dépôt et à la diffusion de documents scientifiques de niveau recherche, publiés ou non, émanant des établissements d'enseignement et de recherche français ou étrangers, des laboratoires publics ou privés. 
Quantification of volatile organic compounds diffusion for virgin geosynthetic clay liners and for a GCL after contact with a synthetic leachate

\author{
S. Paumier ${ }^{1}$, N. Touze-Foltz ${ }^{2}$, L. Mazeas ${ }^{3}$, and A. Guenne ${ }^{4}$ \\ Hydrosystems and Bioprocesses Unit, Cemagref, BP 44, 92163 Antony Cedex, France
}

Abstract:

The effect of the nature of the bentonite (natural sodium or calcium activated) and of cation exchange on diffusive properties of two geosynthetic clay liners are examined. Diffusion laboratory tests were performed to estimate the diffusion coefficients of 1,2-dichloroethane (DCA), dichloromethane (DCM), thrichloroethylene (TCE), toluene and benzene. Both GCLs are needle-punched and come from the same manufacturer. The nature of the bentonite contained in both GCLs was different as a natural sodium bentonite and a calcium activated sodium bentonite were tested. Furthermore, one of the GCLs experienced cation exchange through contact with a synthetic leachate in order to generate an increase in its hydraulic

1 Post-doctorate student, Unité HBAN, BP 44, 92163 Antony Cedex, France. E-mail: sandrine.paumier@laposte.net

${ }^{2}$ PhD, HDR, Cemagref, Unité HBAN, BP 44, 92163 Antony Cedex, France. Corresponding author. E-mail: nathalie.touze@cemagref.fr

3 PhD., Unité HBAN, BP 44, 92163 Antony Cedex, France. E-mail: laurent.mazeas@cemagref.fr

${ }^{4}$ Head of Chemistry laboratory, Cemagref, Unité HBAN, BP 44, 92163 Antony Cedex, France. E-mail: angeline.guenne@cemagref.fr 
conductivity by a factor 8.5 . The objective of this process was to evaluate if an increase in hydraulic conductivity by cation exchange in a GCL would result in a significant increase in diffusion coefficients of volatile organic compounds (VOCs) or not.

Results obtained for both virgin GCLs are very close to each other. No impact of the nature of the bentonite could be evidenced. An increase in the diffusion coefficient was noticed when the GCL had experienced cation exchange while in contact with a synthetic leachate for DCM, DCA and TCE at a given bulk GCL void ratio. The largest increase, by a factor 2.6, was observed for TCE. However, this increase in diffusion coefficient could be balanced by a decrease in the bulk GCL void ratio from 3.9 to 3 . The increase in the diffusion coefficient of VOCs thus does not seem to be of concern, for the range of GCL hydraulic conductivities generated through cation exchange in this study.

Keywords: Geosynthetic clay liners, volatile organic compounds, diffusion, cation exchange, laboratory, modelling

\section{Introduction}

In recent years there have been many advances in the understanding of issues related to the use of geosynthetics, such as geomembranes and geosynthetic clay liners (GCLs), in barriers to contaminants. As a consequence there has also been a significant increase in geoenvironmental applications of geosynthetics (Rowe 2007). As time goes, the knowledge of the behaviour of geosynthetics also increases and the behaviour of the performance of those materials on the long term is better and better controlled. As regards GCLs and their use in bottom liner systems of landfills a number of studies focused on the chemical compatibility between bentonite and leachate. This point has mostly been studied in terms of quantification 
of the evolution of the hydraulic conductivity of GCLs in contact with leachate (Brown and Shackelford 2007; Didier and Comeaga 1995; Guyonnet et al. 2005, 2009; Katsumi et al. 2007; Lake et al. 2008; Petrov and Rowe 1997; Rauen and Benson 2008; Quaranta et al. 1997; Ruhl and Daniel 1997; Shackelford et al. 2000; Shan and Daniel 1991; Shan and Lai 2002; Schroeder et al. 2001; Vasko et al. 2001). The bentonite in GCLs is sensitive to chemical interactions with the hydrating liquid, and ion exchange that occurs in bentonite can alter its physical properties. In particular, exchange of multivalent cations for the native sodium results in increased hydraulic conductivity and decreased swell potential. The hydraulic conductivity increase has been quantified by the previously mentioned authors for a range of experimental conditions.

VOCs are ubiquitous in landfill leachate and most VOCs concentrations do not exhibit decreasing temporal trends over 20 years (Edil 2007). Investigations presented by Edil (2007) in landfills in Wisconsin indicate that the potential for VOC migration remains a problem associated with both clay and composite liners in landfills. Both numerical analyses and field data imply that the current state of practice to contain VOCs is not adequate and VOCs may present a potential environmental problem as time passes. Then a careful review of landfill containment design with a focus on VOCs is needed to prevent wide-spread groundwater contamination around landfills in time. It is thus of interest to study diffusion of VOCs through GCLs. The quantification of diffusion mechanisms of volatile organic compounds (VOCs) has been undertaken for virgin GCLs (Lake and Rowe 2004; Rowe et al. 2005; Ganne et al. 2008) containing natural sodium bentonite.

Consequently, this paper has two objectives. The first one is to study if the nature of the bentonite, natural sodium or calcium activated, has an influence on diffusion coefficients. The second objective is to evaluate if the contact of a GCL with a synthetic leachate, resulting in an increase in the hydraulic conductivity of the GCL in relation with cation exchange, will 3 
have an effect on diffusion coefficients. Indeed, this latter question has not been raised till now, contrarily to what was performed for geomembranes (Islam and Rowe 2009).

After a presentation of the materials used in this study, the paper will describe the methodology used to generate GCLs specimens with an increased hydraulic conductivity as compared to the one of virgin GCLs. Then the methodology of the diffusion tests will be presented. Results will then be discussed and compared to the literature as regards results obtained for virgin samples containing natural sodium bentonite and the effect of the bulk GCL void ratio will be discussed.

\section{Materials and methods}

\section{Geosynthetic clay liners}

Two needle-punched GCLs were studied. Both of them consist of a woven carrier geotextile with a mass per unit area equal to $110 \mathrm{~g} / \mathrm{m}^{2}$ and a non woven needle punched cover geotextile with a mass per unit area equal to $210 \mathrm{~g} / \mathrm{m}^{2}$, both made of polypropylene (PP) fibers. Those geotextiles will respectively be called GTX2 and GTX1 in the following. The two geotextiles are similar to GTX2 and GTX1 tested by Ganne et al. (2008) for the determination of partitioning coefficients, $K_{d}$. For GCL1, the dry mass per unit area of powdered natural sodium bentonite was equal to $5.7 \mathrm{~kg} / \mathrm{m}^{2}$. For GCL2 the dry mass per unit area of powdered calcium activated bentonite was equal to $4.8 \mathrm{~kg} / \mathrm{m}^{2}$. GCL1 and GCL2 correspond respectively to GCLs LX3 and LX7 previously used by Guyonnet et al. (2009) and Rosin-Paumier et al. (2010). Specimens for both studies were sampled in the same rolls, available in the laboratory. 


\section{Volatile organic carbons}

The diffusion of three chlorinated hydrocarbons, namely trichloroethylene (TCE), 1.2dichloroethane (DCA), and dichloromethane (DCM) and two aromatic hydrocarbons, namely benzene and toluene, were studied. Those pollutants are similar to the VOCs previously studied by Lake and Rowe (2004).

This choice is reinforced by the following criteria: (1) high capacity to migrate in soils; (2) high solubility; (3) established or suspected toxicity (reprotoxic, genotoxic); and (4) presence in leachate (Oman and Junestedt 2008). Those VOCs all are part of the list of prioritary substances established by the EC Water Framework Directive (2000/60/CE).

Initial source solution concentrations for diffusion tests were equal to $3.1 \mathrm{mg} / \mathrm{L}$ for TCE, 3 $\mathrm{mg} / \mathrm{L}$ for DCA, $3.3 \mathrm{mg} / \mathrm{L}$ for DCM, $0.81 \mathrm{mg} / \mathrm{L}$ for toluene and $0.9 \mathrm{mg} / \mathrm{L}$ for benzene. Those values of concentrations, in the range of those used by Lake and Rowe (2004), were proven to lead to measurable diffusion transfer parameters in a GCL. Some properties of the VOCs under study are given in Table 1.

\section{Test procedures}

Protocol for the preparation of GCL specimens with an increased hydraulic conductivity

Cation exchange is the main mechanism that can lead to an increase in the hydraulic conductivity of GCLs. A $0.25 \mathrm{~m}$ diameter specimen of GCL was submitted to the permeation of a synthetic leachate (SL), previously used by Guyonnet et al. (2009) with the objective to obtain a leachate composition that was characteristic of a "young" leachate, rich in divalent cations and hence potentially "aggressive"' with respect to a sodium bentonite. 
This specimen size allows to sample at the end of the permeability tests three $0.1 \mathrm{~m}$ diameter specimens than can subsequently be used in the diffusion cells. The permeation was performed according to NF P 84-705 (AFNOR 2008). The testing device was previously presented in Norotte et al. (2004) and Guyonnet et al. (2005, 2009) and its description will thus not be repeated here.

The test started with a saturation phase, under $10 \mathrm{kPa}$, using a $1 \times 10^{-3} \mathrm{M} \mathrm{NaCl}$ solution, i.e., a low electrolyte concentration, with a $0.01 \mathrm{~m}$ hydraulic head. When at least $90 \%$ of equilibrium swelling had been reached as described in Norotte et al. (2004), the confining pressure was increased to $20 \mathrm{kPa}$ and the test fluid was replaced by SL with the hydraulic head increased in a few weeks to $1.2 \mathrm{~m}$. The hydraulic head remained unchanged during three months and a half. Then as the hydraulic conductivity had increased by a factor 5 (see Fig. 1) it was decided to reduce the hydraulic head to $0.6 \mathrm{~m}$ to limit the speed of cation exchange in the GCL until the samples could be removed from the oedopermeater cell for diffusion tests. The objective of this procedure was to keep on increasing the hydraulic conductivity of the GCL but also keeping on controlling its evolution. Fig. 1 illustrates the evolution of the hydraulic conductivity of GCL1 in the oedopermeameter cell as a function of the number of pore volumes percolated. Cation concentrations were measured along the test. The equilibrium was not reached at the end of the test, but this was not the objective. Rather the objective was to obtain a significant increase in the hydraulic conductivity of GCL1 as compared to the hydraulic conductivity of the virgin GCL1. An increase in the hydraulic conductivity of GCL1 by a factor 8.5 was obtained in this experiment. 


\section{Diffusion tests}

\section{Bulk GCL void ratio}

The specified volume GCL diffusion test concept discussed by Rowe et al. (2000) was adopted for VOC diffusion testing. In this type of diffusion, reported by those authors, the virgin GCL specimen was restricted to hydrate to a specified volume height.

The VOC diffusion tests reported herein were performed at bulk void ratios, $e_{b}$, in the range 3 to 3.9. This range was selected to get bulk GCL void ratios values consistent for specimens that had experienced cation exchange and virgin specimens. Indeed in the case of specimens that had experienced cation exchange, the bulk GCL void ratio was imposed by the swelling followed by the thinning of the GCL during the permeability test after contact with the synthetic leachate. The GCL specimens do no longer have a significant ability to swell after the contact with leachate. Diffusion tests were first performed with GCL specimens that had experienced cation exchange, in which the bulk GCL void ratio was calculated. Afterwards, the theoretical thickness, $H_{G C L}$, that virgin GCL samples had to reach was back calculated using Equation 1:

$$
\mathrm{H}_{\mathrm{GCL}}=\left(1+\mathrm{e}_{\mathrm{b}}\right)\left(\frac{\mathrm{M}_{\mathrm{bent}}}{\rho_{\mathrm{b}}\left(1+\mathrm{W}_{0}\right)}+\frac{\mathrm{M}_{\mathrm{geo}}}{\rho_{\mathrm{g}}}\right)
$$

Where $M_{b e n t}=$ mass per unit area of bentonite in the GCL specimen; $\rho_{b}=$ density of bentonite solids; $\mathrm{W}_{0}=$ initial betonite water content; $\mathrm{M}_{\mathrm{geo}}=$ mass per unit area of geotextiles in the GCL specimen; $p_{g}=$ density of polypropylene geotextile solids (Petrov and Rowe 1997).

The swelling of virgin specimens was thus restricted in the diffusion cells in order to obtain identical bulk GCL void ratios for virgin GCL specimens and for GCL specimens that had experienced cation exchange. It was important to ensure that a given value of bulk GCL void ratio could be obtained. Indeed, Lake and Rowe (2000) have shown a linear increase of the 
diffusion coefficient of sodium and chloride with an increase in the bulk GCL void ratio, for void ratios in the range 1.5 to 3 . On the contrary in the study from Lake and Rowe (2004) no significant increase in the diffusion coefficient was noticed for bulk GCL void ratios in the range 4.1 to 4.8 . The evolution of the diffusion coefficient with the bulk GCL void ratio in the zone between those two ranges is unknown and it was thus preferred to try and obtain as far as possible a unique value of bulk GCL void ratio for all specimens.

Lake and Rowe (2004) indicated that bulk GCL void ratios in the range 4.1 to 4.8 corresponded to low normal stresses and that the corresponding diffusion coefficients represented an upper bound of diffusion coefficient values. Such low bulk GCL void ratios were necessary in the tests performed by Lake and Rowe (2004) in order to prevent from breaking of the diffusion cells made of glass. As glass cells were also used in this study, the load in the permeability cell was adjusted so as to ensure that a similar range of bulk GCL void ratios could be reached. Only in the case of one GCL specimen after cation exchange the bulk GCL void ratio was equal to 3 . No virgin sample was prepared with such a low bulk GCL void ratio as it was suspected that the swelling pressure would lead to a break of the glass diffusion cells that were used.

\section{GCL diffusion cell}

The diffusion cell consists of a $0.1 \mathrm{~m}$ internal diameter glass cylinder and two glass caps connected to the glass cylinder by o-rings and metallic bridles that allow a very quick test set up and prevent from the use of any kind of glue to assemble the various parts of the cell (see Fig. 2). Each end of the cell contains a sampling port with a Teflon cap and a second port that can be used for the filling of the cell. Conical glass supports were used in combination with porous stainless steel fritted plates to restrict the hydrated volume of the GCL. The conical glass supports exhibit large circular holes to allow the migration of liquid. 


\section{Diffusion tests set up}

The procedure followed was different for virgin specimens and specimens that had experienced cation exchange.

Virgin GCL specimens were hydrated in the diffusion cell by adding DDW to the receptor chamber of the diffusion cell through the filling port. This was accomplished by connecting a Mariotte bottle to the filling port and applying a hydrating head of approximately $0.01 \mathrm{~m}$ to the receptor chamber. The number and the thickness of the Teflon blocks at the top of the cell were adjusted to allow the swelling of the GCL until the required thickness was reached. Based on the time required to reach chloride equilibrium for the inorganic GCL diffusion tests discussed by Rowe et al. (2000), the GCL was allowed to hydrate for 45 days prior to the diffusion test, consistently with what was suggested by Lake and Rowe (2004).

GCL1 that had experienced cation exchange was removed from the oedopermeameter. Three $0.1 \mathrm{~m}$ specimens were immediatly cut off from GCL1 that had experienced cation exchange and installed in three diffusion cells. A $0.01 \mathrm{~m}$ hydraulic head was applied to each disc using a Mariotte bottle during 24 hours before the beginning of the test in order to prevent from drying of the specimen as pollutants were added in the cell on the next day.

Then once the specimens were ready, the following procedure was used, both for virgin specimens and specimens that had experienced cation exchange: (1) $800 \mathrm{~mL}$ of DDW was added to the source chamber of the diffusion cell; (2) $50 \mathrm{~mL}$ of the source solution was transferred to the water of the source chamber; (3) the source chamber was filled with DDW to minimize the headspace. The source and receptor sampling ports were sealed with a Teflon-lined septum throughout the diffusion test. The test configuration ensured that there was no hydraulic gradient during testing. 


\section{Sampling in tests cells}

The solutions were immediately sampled to establish initial concentrations of each VOC contaminant in the source solution and receptor solution.

Afterwards, samplings were performed at regular time intervals in both the source and receptor. Samplings were performed by inserting two glasses syringes into the chamber through the Teflon-lined septum of the sampling ports. The first syringe with a long needle allowed sampling $2 \mathrm{ml}$ of the solution at the centre of the chamber. The second syringe with a short needle was used to inject DDW to avoid depression inside the chamber. Initially, $2 \mathrm{~mL}$ and $4 \mathrm{~mL}$ samples were withdrawn from the source and receptor chambers respectively. As tests progressed and concentrations increased in the receptor, the volume sampled in the receptor was reduced to $2 \mathrm{~mL}$. The dilution was neglected in this study as each chamber volume is close to $1550 \mathrm{ml}$.

\section{Evaluation of Mass Losses during Diffusion Test}

Blank tests were conducted using the diffusion apparatus without any GCL present to allow an assessment of mass loss due to sorption onto the Teflon coated stirrers or cell. Blank tests were performed with and without the porous stainless steel fritted plates in the cell. In the case of DCM, TCE and DCA, no change was noticed between both situations and no sorption onto the cell components was detected. On the contrary $46 \%$ of benzene and $35 \%$ of toluene were adsorbed on the stainless steel fritted plates. An attempt was made to account for sorption on the stainless steel fritted plates when modelling diffusion. Indeed, based on the quantification of mass losses, a partitioning coefficient for benzene and toluene on the stainless steel fritted plates could be determined, respectively equal to $8.3 \mathrm{~mL} / \mathrm{g}$ and $12.8 \mathrm{~mL} / \mathrm{g}$ for benzene and toluene. However, the evolution of the toluene and benzene concentration was not significant enough in the reservoir to quantify diffusion coefficients. Consequently it was decided not to 
model diffusive transfers for toluene and benzene from the experiments described in this paper.

\section{Analytical methods}

\section{Preparation of the solutions}

The source solution for VOC diffusion tests was prepared three days prior to testing in a 1.129L (nominal size) glass bottle. The bottle was filled with deionised distilled water (DDW). Then a $1.5 \mathrm{ml}$ open vial containing pure VOCs diluted in methanol was entirely placed inside the bottle. After mixing, the source solution was stored at $7^{\circ} \mathrm{C}$ in a dark place. The source solution was used both in the source of the diffusion cells and for preparing standards for calibration of the gas chromatograph. The internal standard solution contained two deuterated components: Toluene-d8 and 1.2 dichloroethane-d4. Pure components were first diluted in methanol then in water.

\section{Quantitative analysis}

The quantification of concentrations of VOCs was performed by Head Space Gas Chromatography - Mass Spectrometry (HS-GC-MS). $5 \mathrm{~mL}$ of the sample were incubated at $70^{\circ} \mathrm{C}$ during 10 minutes. $1 \mathrm{~mL}$ of the gas phase was injected into GC-MS. A split/splitless injector was used in the split mode (split flow $12 \mathrm{~mL} / \mathrm{min}$ ). The VOC mixture was then separated through a DB-5 capillary column $(0.25 \mathrm{~mm}$ in inner diameter and $60 \mathrm{~m}$ in length) using a $1.2 \mathrm{ml} / \mathrm{min}$ helium flow. Toluene d-8 was used as internal standard for quantification of toluene and benzene and DCA d-4 for DCA, DCM and TCE. 


\section{VOCs diffusion coefficient quantification in GCLs}

Rowe and Booker (1984) developed a model for predicting one-dimensional contaminant transport through soils of finite thickness and to account for realistic landfill parameters such as surface boundary concentrations changing with time (as is the case for MSW landfills). Rowe et al. (2000), Lake and Rowe (2004) and Rowe et al. (2005) applied this model to predict one-dimensional contaminant transport for a single reactive solute (no degradation) through a saturated GCL, which utilises Equation 2:

$n \frac{\partial C}{\partial t}=n D_{e} \frac{\partial^{2} C}{\partial z^{2}}-\rho_{d} K_{d} \frac{\partial C}{\partial t}$

where $C=$ concentration in the GCL at depth $z$ and time $t ; n=$ total porosity of the GCL ; $D_{e}=$ effective diffusion coefficient; $\rho_{d}=$ dry density; and $K_{d}=$ partitioning coefficient

Diffusion coefficients can be estimated by solving Equation 2 in combination with finite mass boundary conditions (see Rowe et al. 2004) for the test set-up. Finite mass refers to the fact that the concentration is changing throughout time at both boundary conditions, owing to mass transfer through the GCL and any sampling of the laboratory tests. Mathematically, the concentration at any time in the source (contaminated) compartment, $C_{t}(t)$, is given by Equation 3:

$C_{t}(t)=C_{0}-\frac{1}{H_{s}} \int_{0}^{1} f_{t}(\tau) d \tau$

where $\mathrm{C}_{0}=$ initial concentration in the source solution; $H_{s}=$ height of source fluid (volume of source fluid per unit area); $f_{t}(t)$ is the mass flux of contaminant into the GCL at any time $t$. The concentration in the receptor compartment at any time, $C_{b}(t)$, can be expressed similarly as :

$C_{b}(t)=C_{b 0}-\frac{1}{H_{b}} \int_{0}^{1} f_{b}(\tau) d \tau$ 
where $\mathrm{C}_{\mathrm{b} 0}=$ initial concentration in the receptor solution; $\mathrm{H}_{\mathrm{b}}=$ height of the receptor (volume of receptor chamber per unit area); $f_{b}(t)=$ mass flux of contaminant into the receptor chamber at any time $\mathrm{t}$.

Diffusion was modelled as previously performed by Rowe et al. (2005) for a layered system comprised of: (1) the upper stainless steel porous fritted plate; (2) the cover geotextile; (3) the bentonite layer; (4) the carrier geotextile; and (5) the lower stainless steel fritted plate. The bentonite layer was considered as fiber free. The physical properties of these layers are given in Table 2. The partitioning coefficients of the VOCs presented in Table 3 are based on the results from the batch immersion/sorption tests performed by Ganne et al. (2008) and Ganne (2008) on the same GCLs as the ones used in this study. Those values are consistent with results from the literature. As very low values of partitioning coefficients were obtained in the literature for the VOCs under study on bentonite, this parameter was not quantified in this study. Rather values from the literature were used. Due to the fact that results obtained with both GCLs whatever the nature of the bentonite in terms of diffusion curves were very similar, it was assumed that the nature of the bentonite had very little effect on sorption. It is all the more logical as it is the organic matter content that dominates the sorption of VOCs in soils and this content is identical for both bentonites.

Consequently, the values by Lake and Rowe (2004) obtained for a natural sodium bentonite were adopted in this study (see Table 4).

The effective diffusion coefficient for the plate was taken to be that in free solution, $D_{0}$ which is consistent with the assumption made by Rowe et al. (2005). There was little bentonite in the cover and carrier geotextile before hydration so that the effective diffusion coefficient of the various compounds through the geotextile pores was also taken to be that in free solution $D_{0}$. 
The diffusion coefficient for the bentonite layer was obtained by the iterative solution of Equation 2, until a statistically based best-fit curve was obtained corresponding to the minimum summation of square error (SSE) according to what was previously performed by Rowe et al. (2005).

Afterwards, an equivalent partitioning coefficient, $K_{\text {deq }}$, for the entire GCL was calculated according to the solution suggested by Rowe et al. (2005) adapted for the case of this paper where the presence of fibers in the bentonite core is not taken into account in the modelling. the expression of $K_{d e q}$ is given in Equation 5:

$$
K_{d e q}=\frac{m_{d b} \cdot K_{d b}+m_{d b G T 1} \cdot K_{d b G T 1}+m_{d b G T 2} \cdot K_{d b G T 2}}{m_{d b}+m_{d b G T 1}+m_{d b G T 2}}
$$

where $\mathrm{m}_{\mathrm{db}}, \mathrm{m}_{\mathrm{dbGT1}}$ and $\mathrm{m}_{\mathrm{dbGT2}}$ respectively represent the dry mass of bentonite, of geotextile 1 and geotextile 2 in the GCL and $\mathrm{K}_{\mathrm{db}}, \mathrm{K}_{\mathrm{dbGT1}}$ and $\mathrm{K}_{\mathrm{dbGT2}}$ are the partitioning coefficients in bentonite, geotextile 1 and geotextile 2 respectively.

A global diffusion coefficient for the whole GCL could then be recalculated for each experiment and each contaminant, treating the whole GCL as a homogeneous material.

\section{Results and discussion}

\section{Virgin GCL samples}

Figs. 3 and 4 show the observed variations of DCM, DCA and TCE (normalized with respect to the initial concentrations) in the source and receptor compartments at $22^{\circ} \mathrm{C}$. Each data point corresponds to the average for two GCL samples of a single evaluation of the concentration by GC/MS. The best-fit theoretical curves generated by solving the diffusion equation with the appropriate boundary conditions are also shown on those figures. 
The estimated diffusion coefficients on the bentonite are given in Tables 5 and 6 for the whole GCL.

The diffusion coefficient presented in this study are consistent with the ones given by Lake and Rowe (2004), between 2 and $3 \times 10^{-10} \mathrm{~m} / \mathrm{s}$ for bulk GCL void ratios in the range 4.1 to 4.8 . The diffusion coefficient is slightly larger for GCL 2 than for GCL1. This result cannot however be linked to the nature of the bentonite. Indeed, the bulk GCL void ratio of GCL2 is equal to 3.9 and the one of GCL 1 equal to 3.7. This increase in $e_{b}$ value could explain the increase in diffusion coefficient. It thus seems reasonable from those results to conclude that there was no significant impact of the nature of the bentonite on the diffusion coefficient in the study presented in this paper.

Consistently with the observations performed by Rowe et al. (2005) the value of the diffusion coefficient for the whole GCL is larger than that of the bentonite, as the less tortuous geotextile layers have been combined with the bentonite layer to obtain bulk parameters for the GCL.

\section{Diffusion through GCL specimens that had experienced cation exchange}

Fig. 5 shows the observed variations of DCM, DCA and TCE (normalized with respect to the initial concentrations) in the source and receptor compartments at $22^{\circ} \mathrm{C}$ for specimens that had experienced cation exchange with $\mathrm{e}_{\mathrm{b}}$ equal to 3.9. In the case $\mathrm{e}_{\mathrm{b}}$ is equal to 3.9 , the result obtained corresponds to a duplicate whereas in the case $e_{b}$ is equal to 3 results obtained correspond to a unique GCL specimen (Tables 5 and 6).

In the case of the GCL specimen that had experienced cation exchange, the concentrations of TCE were not measured to decrease in the source. Results were interpreted based only on the evolution of concentration obtained in the receptor, as an adjustment could not be made on data in the source, and must thus be used with care. 
From Tables 5 and 6 it can be observed that an increase in the diffusion coefficient is observed for the GCL specimen that had experienced cation exchange as compared to the virgin GCL specimens for a bulk GCL void ratio equal to 3.9.

The largest increase in diffusion coefficient was observed for TCE as compared to the other contaminants.

The maximum increase in diffusion coefficient obtained for TCE is equal to 2.6. This ratio is not as large as the increase in the hydraulic conductivity of the GCL.

A detrimental effect of cation exchange on the hydraulic conductivity of a GCL is thus not necessarily indicative of a detrimental effect on the diffusion coefficient of VOCs through GCLs. This result has to be confirmed for other GCLs and other pollutants.

\section{Effect of the bulk GCL void ratio}

The effect of the bulk GCL void ratio on the values of the diffusion coefficient can be studied from the results obtained in the case of the GCL specimen that had experienced cation exchange. It can be noticed from the data presented in Tables 5 and 6 , respectively presenting the values of diffusion coefficient for the bentonite and for the whole GCL that an increase in the bulk GCL void ratio between 3 and 3.9 leads to an increase in the diffusion coefficient for DCM and DCA. Such a result was not obtained for TCE. Those results however must be taken with care as has previously been mentioned for this pollutants.

The decrease in void ratio from 3.7 to 3 is sufficient to balance the increase in the diffusion coefficient that is due to the increase in hydraulic conductivity of the GCL due to cation exchange. Indeed, the value of diffusion coefficient for DCM is lower in the case of the GCL1 specimen that had experienced cation exchange and almost equal for DCA to the value obtained for the virgin GCL and a bulk GCL void ratio equal to 3.7. 


\section{Conclusions}

One of the objectives of this paper was to evaluate if there could be a potential impact of the nature of the bentonite on diffusive transfers through GCLs. Two different GCLs from the same manufacturers containing either a natural sodium bentonite or a calcium activated bentonite were tested. Results were obtained for DCA, DCM and TCE. Results obtained show a slight increase in the diffusion coefficient for the GCL containing calcium activated bentonite as compared to the one containing natural sodium bentonite. However, the bulk GCL void ratio was also slightly larger in the case of the GCL containing the calcium activated bentonite so that the very moderate increase cannot be attributed to the nature of the bentonite. It thus seems reasonable from those results to conclude that there was no significant impact of the nature of the bentonite on the diffusion coefficient.

The second objective of this paper was to evaluate the impact of the increase in hydraulic conductivity of a GCL due to cation exchange on the evolution of the diffusion coefficient. This study was undertaken for the GCL containing natural sodium bentonite. Samples with similar GCL bulk void ratios could be obtained for the virgin GCL specimen and the GCL specimen that had experienced cation exchange. An increase in the diffusion coefficient was noticed. The largest increase was observed for TCE: the diffusion coefficient of the bentonite increased by a factor 2.6. This factor is not comparable to the factor 8.5 which was obtained through the cation exchange phenomenon on the hydraulic conductivity of the GCL. From this result it seems that a moderate increase of the diffusion coefficient can be expected for VOCs even if GCLs experience some cation exchange that will have a significant effect on their hydraulic conductivity.

This increase in diffusion coefficient was balanced by a decrease in the bulk GCL void ratio from 3.9 to 3. Indeed for the GCL with increased hydraulic conductivity after cation exchange 
and a bulk GCL void ratio equal to 3, the diffusion coefficient were as low, if not lower, than the ones obtained for the virgin GCLs.

\section{Acknowledgements}

The study presented in this paper was funded successively by (1) ANR Precodd for the Bioréacteur research program which partners were EEDEMS, Cemagref, LTHE, INSA de Lyon, BRGM, Suez-environnement and Véolia Propreté, and (2) RGC\&U (C2D2) for the Duragéos research program labelled by Axelera and Advancity which partners are IFSTTAR, Cemagref, LTHE ENTPE, PIMM Arts et Métiers ParisTech, Suez-environnement and Véolia Propreté. 


\section{References}

AFNOR (2008). "Geosynthetic clay liners. Determination of the swelling, flow and permeability characteristics of geosynthetic clay liners (GCL) using an oedopermeameter. Characterisation test and performance test". English version, $22 \mathrm{p}$.

Brown, L.C., and Shackelford, C.D. (2007). "Hydraulic conductivity of a geosynthetic clay liner to a simulated animal waste solution”. Transactions of the ASAE, 50(3), 831-841.

Didier, G., and Comeaga, L. (1995). "Influence of initial hydratation conditions on GCL leachate permeability". Testing and acceptance criteria for geosynthetic Clay Liner. American Society for Testing and materials, 1308, 181-195.

Edil, T.B. 2007. Is aqueous-phase VOC transport from modern landfills a potential environmental problem? Proceedings Sardinia 2007, 11th International Waste Management and Landfill Symposium, 1-5 October 2007, S. Margherita di Pula, Cagliari, Sardinia, Italy, 8 p.

Egloffstein, T.A. (2001). "Natural bentonites - influence of the ion exchange and partial dessication on permeability and self-healing capacity of bentonites used in GCLs". Geotext. Geomembr., 19, 427-444.

Ganne (2008). "Quantification des transferts diffusifs de micropolluants dans les Géosynthétiques Bentonitiques et impacts sur leur vieillissement”. Rapport final Ademe, $33 \mathrm{p}$.

Ganne, A., Touze-Foltz, N., Mazeas, L., Guenne, A., and Epissard, J. (2008). "Experimental determination of sorption and diffusion of organic pollutants through GCLs”. Proc. Eurogeo 4, 7p. 
Guyonnet, D., Gaucher, E., Gaboriau, H., Pons, C.-H., Clinard, C., Norotte, V., and Didier, G. (2005). "Geosynthetic clay liner interaction with leachate: correlation between permeability, microstructure, and surface chemistry". ASCE J. Geotech. Geoenv; Eng., 131(6), 740-749.

Guyonnet, D., Touze-Foltz, N., Norotte, V., Pothier, C., Didier, G., Gailhanou, H., Blanc, P., and Warmont, F. (2009). "Performance-based indicators for controlling geosynthetic clay liners in landfill applications". Geotext. Geomembr., 27, 321-331.

Katsumi, T., Ishimori, H., Ogawa, A., Yoshikawa, K., Hanamoto, K., and Fukagawa, R. (2007). "Hydraulic conductivity of nonprehydrated geosynthetic clay liners permeated with inorganic solutions and waste leachates". Soils and Foundations, 47(1), 79-96.

Islam, M.Z., and Rowe, R.K. (2009). "Permeation of BTEX through unaged and aged HDPE Geomembranes". ASCE J. Geotech. Geoenv; Eng, 135(8), 1130-1140.

Journal Officiel (2000). "Directive 2000/60/CE du Parlement européen et du Conseil du 23 octobre 2000 établissant un cadre pour une politique communautaire dans le domaine de l'eau". Journal officiel n L 327 du 22/12/2000, 1-73.

Lake, C.B., Cleary, B.A., Gordon, R., and Jamieson, R. (2008). “GCL compatibility with livestock mortality leachate". Proc. Geoamericas, Cancun, 2-5 March 2008, 69-75.

Lake, C. B., and Rowe, R. K. (2004). "Volatile organic compound diffusion and sorption coefficients for a needle-punched GCL". Geosynt. Int., 11(4), 257-272.

Lake, C. B., and Rowe, R. K. (2000). "Diffusion of sodium and chloride through geosynthetic clay liners". Geotext. Geomembr., 18, 103-131.

Norotte, V., Didier, G., Guyonnet, D., and Gaucher, E. (2004). "Evolution of GCL hydraulic performance during contact with landfill leachate". Advances in Geosynthetic Clay Liner Technology: 2nd Symposium, ASTM STP 1456, Mackey and von Maubeuge (eds.), ASTM International, West Conshohocken, PA., 41-52. 
Oman C.B., and Junestedt C. (2008). "Chemical characterization of landfill leachates - 400 parameters and compounds". Waste Management 28, 1876-1891.

Petrov; R.J., and Rowe, R.K. (1997). “Geosynthetic clay liner-chemical compatibility by hydraulic conductivity testing: factors impacting its performance”. Canadian Geotechnical Journal 34(6), 863-885.

Quaranta, J., Gabr, M., and Bowders, J. (1997). "First-exposure performance of the bentonite component of a GCL in a low-pH calcium enriched environment". Testing and acceptance criteria for geosynthetic clay liners, ASTM STP 1308, 162-177.

Rosin-Paumier, S., Touze-Foltz, N., Pantet, A., Monnet, P., Didier, G., Guyonnet, D., and Norotte, V. (2010). "Swell index, oedopermeametric, filter press and rheometric tests for identifying the qualification of bentonites used in GCLs”. Geosynt. Int., 17(1) (in Press).

Rauen, T.L., and Benson, C.H. (2008). "Hydraulic conductivity of a geosynthteic clay liner permeated with leachate from a landfill with leachate recirculation. Proc. Geoamericas, Cancun, 2-5 March 2008, 76-83.

Rowe, R.K. (2007). "Advances and remaining challenges for geosynthetics in geoenvironmental engineering applications". 23rd Manual Rocha Lecture, Soils and Rocks $30(1), 3-30$.

Rowe, R. K., and Booker, J. R. (1984). "1-D pollutant migration in soils of finite depth. J. Geotech. Eng., 111(4), 479-499.

Rowe, R. K., Lake, C. B., and Petrov, R. J. (2000). “Apparatus and procedures for assessing inorganic diffusion coefficients through geosynthetic clay liners". Geotech. Testing J., 23(2), 206-214.

Rowe, R.K., Mukunoki, T., and Sangam, H.P. (2005). "BTEX diffusion and sorption for a geosynthetic clay liner at two temperatures". ASCE J. Geotech. Geoenv; Eng., 131(1), $1211-1221$. 
Rowe, R;K., Quigley, R.M., Brachman, R.W.I., and Booker, J.R. (2004). “Barrier systems for waste disposal facilities". $2^{\text {nd }}$ Edition, E\&F Spon, 587 p.

Ruhl, J. L., and Daniel, D. E. (1997). “Geosynthetic clay liners permeated with chemical solutions and leachates". ASCE J. Geotech. Geoenv; Eng., 123(4), 369-381.

Schroeder, C., Monjoie, A., Illing, P., Dosquet, D., and Thorez, J. (2001). “Testing a factoryprehydrated GCL under several conditions”. Proc. Sardinia 2001, 8th International Waste Management and Landfill Symposium, Cagliari, Italy, 187-196.

Shackelford, C. D., Benson, C. H., Katsumi, T., Edil, T. B., and Lin, L. (2000). "Evaluating the hydraulic conductivity of GCLs permeated with non-standard liquids". Geotext. Geomembr., 18(2-4), 133-161.

Shan, H. Y., and Daniel, D. E. (1991). "Results of laboratory tests on a geotextile/bentonite liner material". Proc. Geosynthetics 1991, IFAI, 2, 517-535.

Shan, H. Y., and Lai, Y. J. (2002). "Effect of hydrating liquid on the hydraulic properties of geosynthetic clay liners". Geotext. Geomembr., 20, 19-38.

Vasko, S., Jo, H. Y., Benson, C. H., Edil, T. B., and Katsumi, T. (2001). "Hydraulic conductivity of partially prehydrated geosynthetic clay liners permeated with aqueous calcium chloride solutions". Proc. Geosynthetics 1991, IFAI, 1, 685-699. 
Table 1. Selected properties of VOCs tested (from Lake and Rowe, 2004)

\begin{tabular}{|c|c|c|c|c|c|c|}
\hline Compound & $\begin{array}{l}\text { Specific } \\
\text { density } \\
(\mathrm{g} / \mathrm{ml})\end{array}$ & $\begin{array}{l}\text { Solubility } \\
\text { in water } \\
(\mathrm{g} / \mathrm{l})\end{array}$ & $\begin{array}{l}\text { Vapour } \\
\text { pressure } \\
(\mathrm{kPa})\end{array}$ & $\begin{array}{l}\text { Octanol- } \\
\text { water } \\
\text { partition } \\
\text { coefficient } \\
\operatorname{logK}_{\mathrm{ow}}\end{array}$ & $\begin{array}{l}\text { Dielectric } \\
\text { constant }\end{array}$ & $\begin{array}{l}\text { Aqueous } \\
\text { diffusion } \\
\text { coefficient } \\
\text { at } \\
\text { infinite } \\
\text { dilution } \\
\left(\mathrm{m}^{2} / \mathrm{s}\right)\end{array}$ \\
\hline$\overline{\mathrm{DCM}}$ & $\begin{array}{l}1.32 \\
\left(20^{\circ} \mathrm{C}\right)\end{array}$ & $13.0-19.4$ & $\sim 60$ & 1.15 & 8.9 & $1.26 \times 10^{-9}$ \\
\hline DCA & 1.25 & $8.0-8.3$ & $\sim 9$ & 1.47 & $\begin{array}{l}10.4 \\
\left(20^{\circ} \mathrm{C}\right)\end{array}$ & $1.08 \times 10^{-9}$ \\
\hline TCE & $\begin{array}{l}1.46 \\
\left(20^{\circ} \mathrm{C}\right)\end{array}$ & $1.1-1.5$ & $\sim 10$ & 2.42 & $3.3\left(28^{\circ} \mathrm{C}\right)$ & $0.99 \times 10^{-9}$ \\
\hline Benzene & 0.87 & $1.7-1.8$ & $\sim 16$ & 2.13 & $2.3\left(20^{\circ} \mathrm{C}\right)$ & $1.16 \times 10^{-9}$ \\
\hline Toluene & 0.86 & $0.5-0.6$ & $\sim 4$ & 2.69 & 2.4 & $0.97 \times 10^{-9}$ \\
\hline
\end{tabular}

All properties are at $25^{\circ} \mathrm{C}$ unless otherwise indicated.

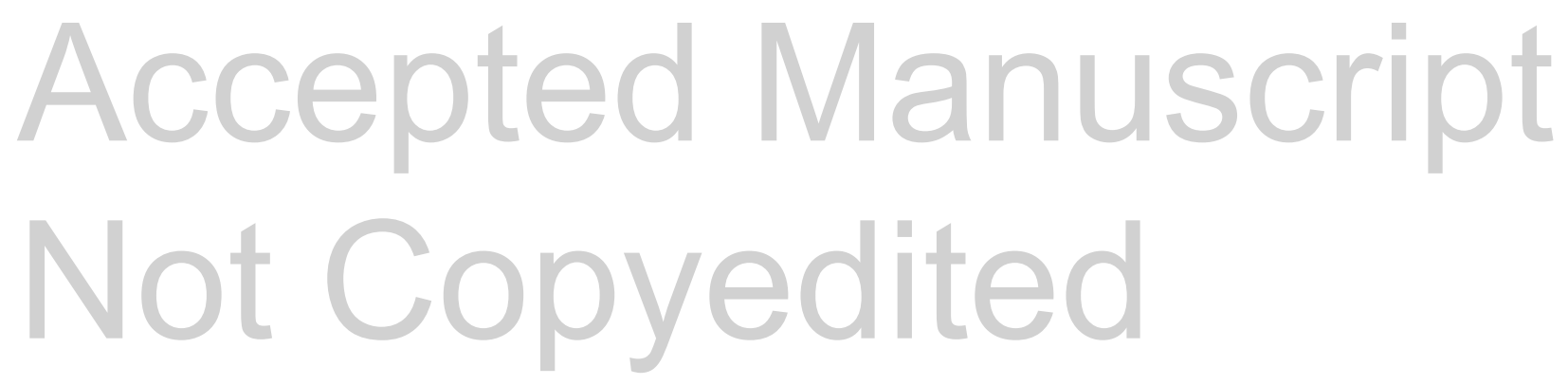


Table 3. Values of partitioning coefficients $\mathrm{K}_{\mathrm{d}}$ in $\mathrm{mL} / \mathrm{g}$ at $22^{\circ} \mathrm{C}$ from (a) Ganne et al. (2008) and (b) Ganne (2008) for GTX 1 and GTX 2

\begin{tabular}{lll}
\hline Contaminants & GTX1 & GTX2 \\
\hline DCA & $11^{\mathrm{a}}$ & $7-20^{\mathrm{a}}$ \\
TCE & $91-102^{\mathrm{a}}$ & $91-98^{\mathrm{a}}$ \\
DCM & $3-11^{\mathrm{b}}$ & $5-14^{\mathrm{b}}$ \\
\hline
\end{tabular}

Table 4. Synthesis of partitioning coefficients $\mathrm{K}_{\mathrm{d}}$ in $\mathrm{mL} / \mathrm{g}$ for the bentonites from Lake and Rowe (2004) at $22^{\circ} \mathrm{C}$.

Contaminants Lake and Rowe (2004)

\begin{tabular}{ll}
\hline DCA & 0.3 \\
TCE & 0.9 \\
DCM & 0.3 \\
\hline
\end{tabular}

\section{Accepted Manuscript Not Copyedited}


Table 2. Physical properties of the various layers used for modelling

\begin{tabular}{llll}
\hline & Thickness $\left(\times 10^{-3} \mathrm{~m}\right)$ & $\mathrm{n}()$ & $\rho_{\mathrm{d}}\left(\mathrm{kg} / \mathrm{m}^{3}\right)$ \\
\hline Stainless steel fritted plate & 3.0 & 0.38 & 4,837 \\
Cover geotextile & 1.4 & 0.83 & 170 \\
Bentonite layer & $9.65-10.5^{1}$ & $0.81-0.83^{1}$ & $450-500^{1}$ \\
& $7.7-10.6^{2}$ & $0.78-0.83^{2}$ & $450-600^{2}$ \\
Carrier geotextile & 0.7 & 0.83 & 160 \\
\hline
\end{tabular}

for virgin GCLs

${ }^{2}$ for GCL 1 after cation exchange

Table 5. Synthesis of the diffusion coefficients obtained (in $\mathrm{m}^{2} / \mathrm{s}$ ) for the bentonite after modelling of the experimental results from this study

\begin{tabular}{lllll}
\hline & GCL1 & GCL2 & \multicolumn{2}{c}{$\begin{array}{c}\text { GCL1 after cation } \\
\text { exchange }\end{array}$} \\
& & & & \\
\hline DCM & $2.3 \times 10^{-10}$ & $2.4 \times 10^{-10}$ & $2.1 \times 10^{-10}$ & $3.1 \times 10^{-10}$ \\
DCA & $1.9 \times 10^{-10}$ & $2.2 \times 10^{-10}$ & $2.0 \times 10^{-10}$ & $2.6 \times 10^{-10}$ \\
TCE & $1.0 \times 10^{-10}$ & $1.2 \times 10^{-10}$ & $2.6 \times 10^{-10}$ & $2.6 \times 10^{-10}$ \\
$\mathrm{e}_{\mathrm{b}}$ & 3.7 & 3.9 & 3.0 & 3.9 \\
\hline
\end{tabular}

Accepted Manuscript

Not Copyedited 
Table 6. Synthesis of the diffusion coefficients obtained for the GCLs (in $\mathrm{m}^{2} / \mathrm{s}$ ) after modelling of the experimental results from this study and values of $\mathrm{K}_{\mathrm{deq}}$ for the entire GCLs

\begin{tabular}{llllll}
\hline & GCL1 & GCL2 & GCL1 after cation & $\mathrm{K}_{\text {deq }}(\mathrm{mL} / \mathrm{g})$ \\
& & \multicolumn{5}{c}{ exchange } \\
\hline DCM & $2.9 \times 10^{-10}$ & $3.0 \times 10^{-10}$ & $3 \times 10^{-10}$ & $3.8 \times 10^{-10}$ & 1 \\
DCA & $2.8 \times 10^{-10}$ & $3.0 \times 10^{-10}$ & $3 \times 10^{-10}$ & $3.6 \times 10^{-10}$ & 2.5 \\
TCE & $3.9 \times 10^{-10}$ & $4.2 \times 10^{-10}$ & $7 \times 10^{-10}$ & $7 \times 10^{-10}$ & 18.8 \\
$\mathrm{e}_{\mathrm{b}}$ & 3.7 & 3.9 & 3.0 & 3.9 & \\
\hline
\end{tabular}

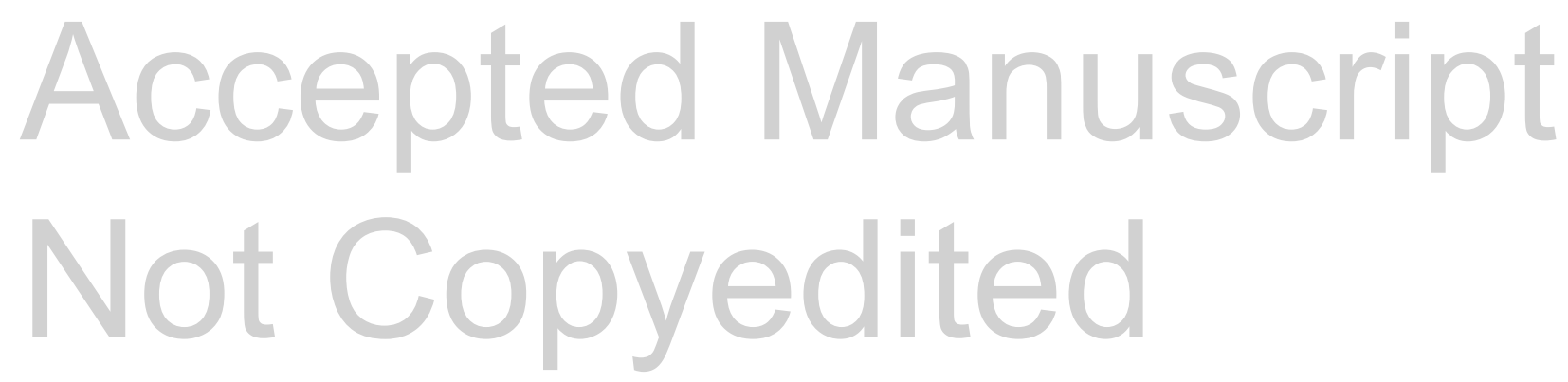




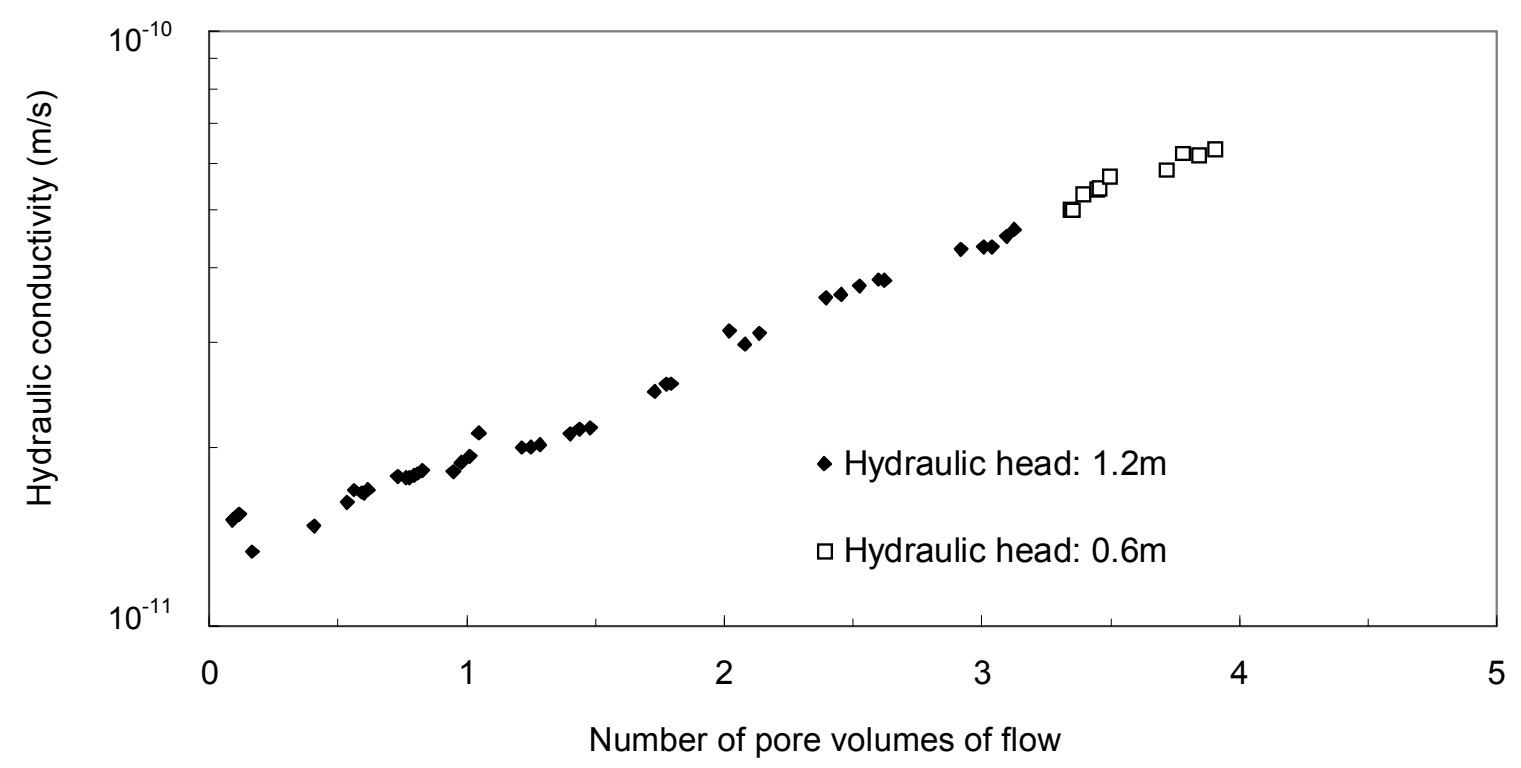

Fig. 1. Evolution of the hydraulic conductivity of GCL1 in contact with SL as a function of the number of pore volumes percolated

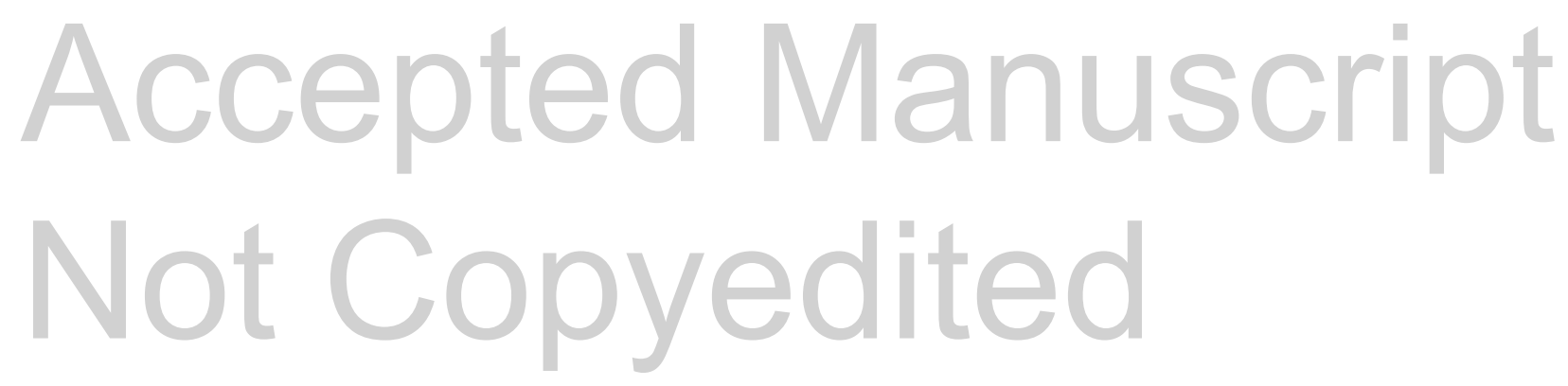




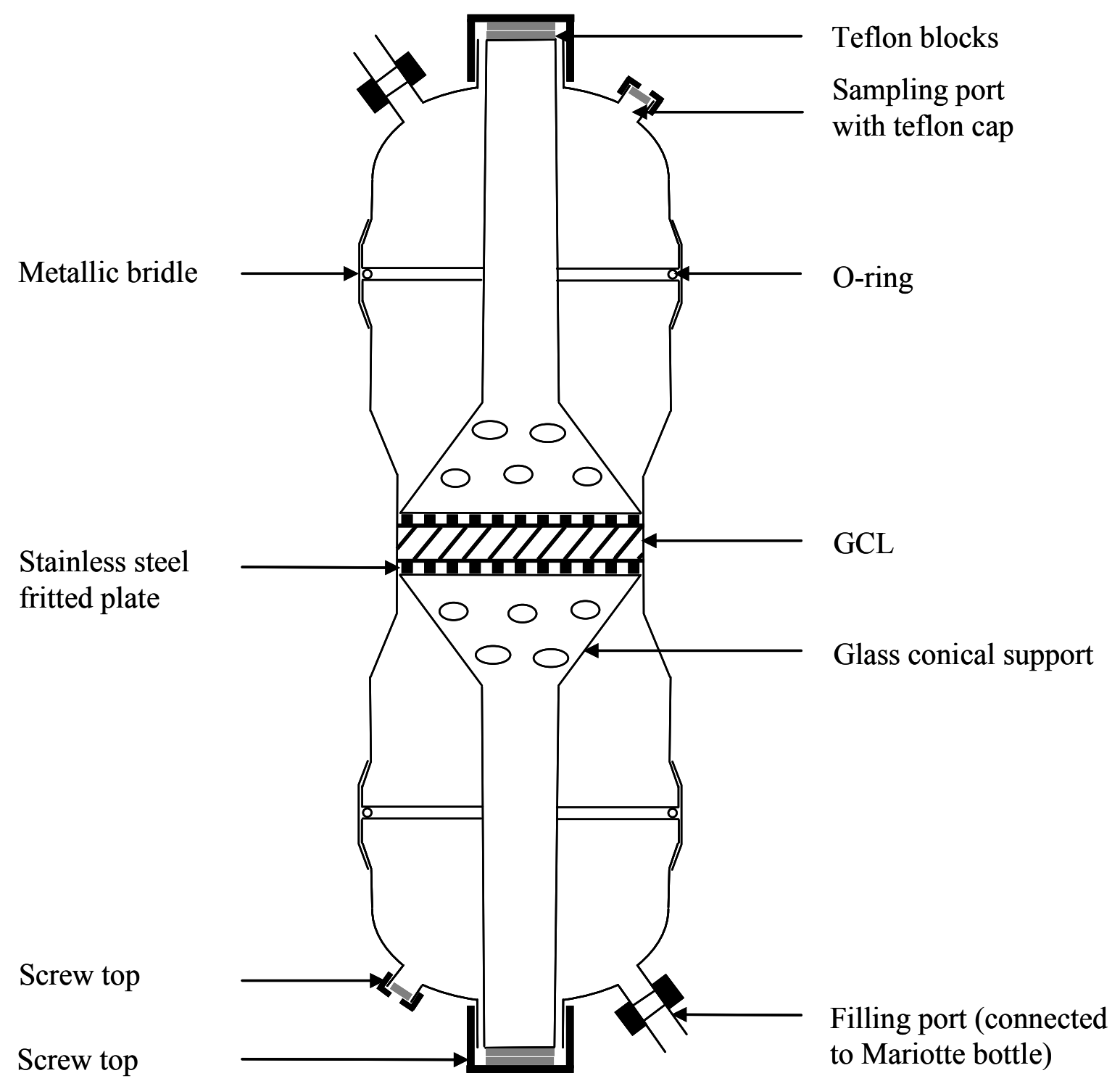

Fig. 2. Schematic of the diffusion cell

\section{Accepted Manuscript Not Copyedited}


Figure 3.pdf

Journal of Geotechnical and Geoenvironmental Engineering. Submitted May 13, 2010; accepted February 11, 2011; posted ahead of print February 14, 2011. doi:10.1061/(ASCE)GT.1943-5606.0000525

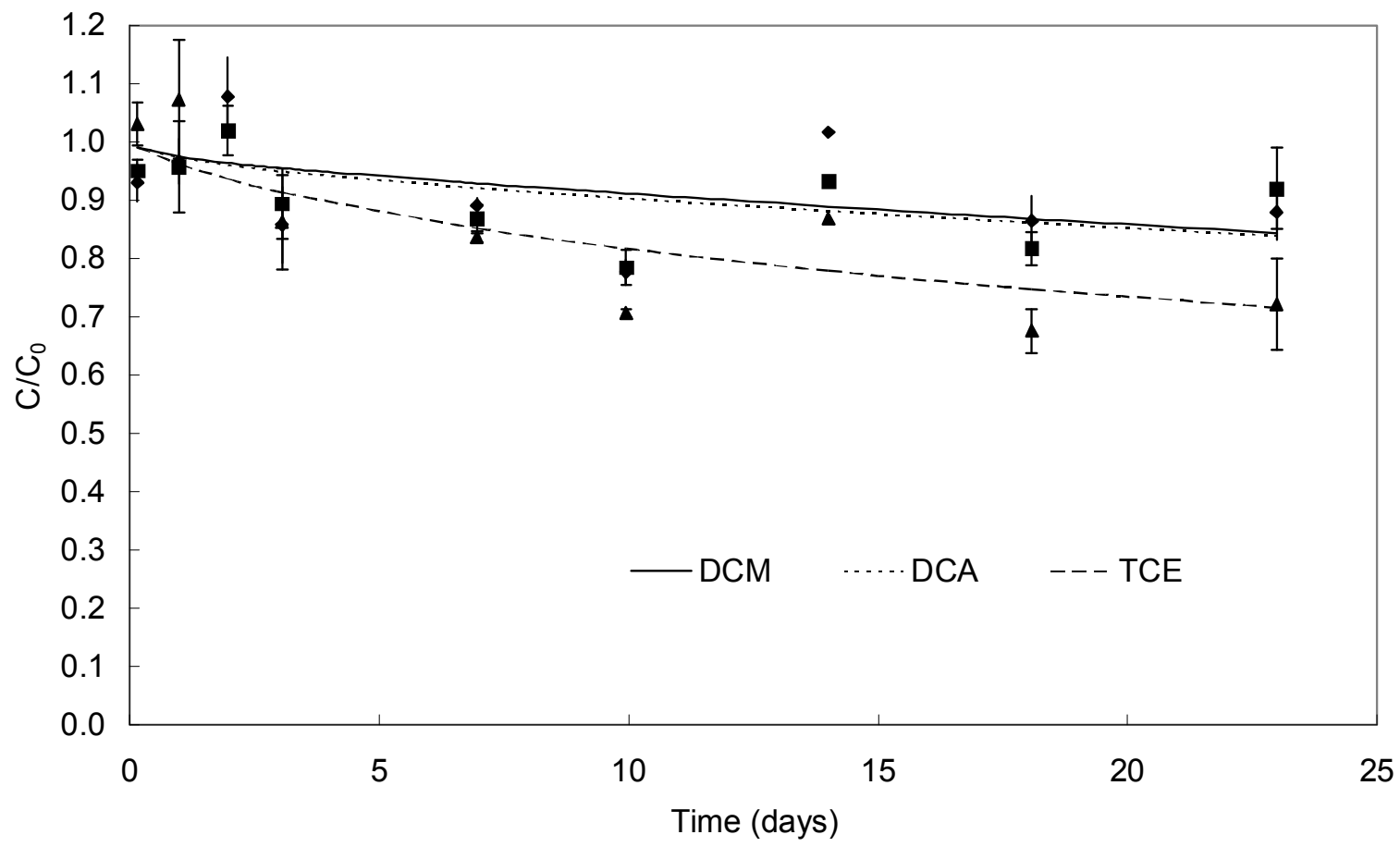

(a)

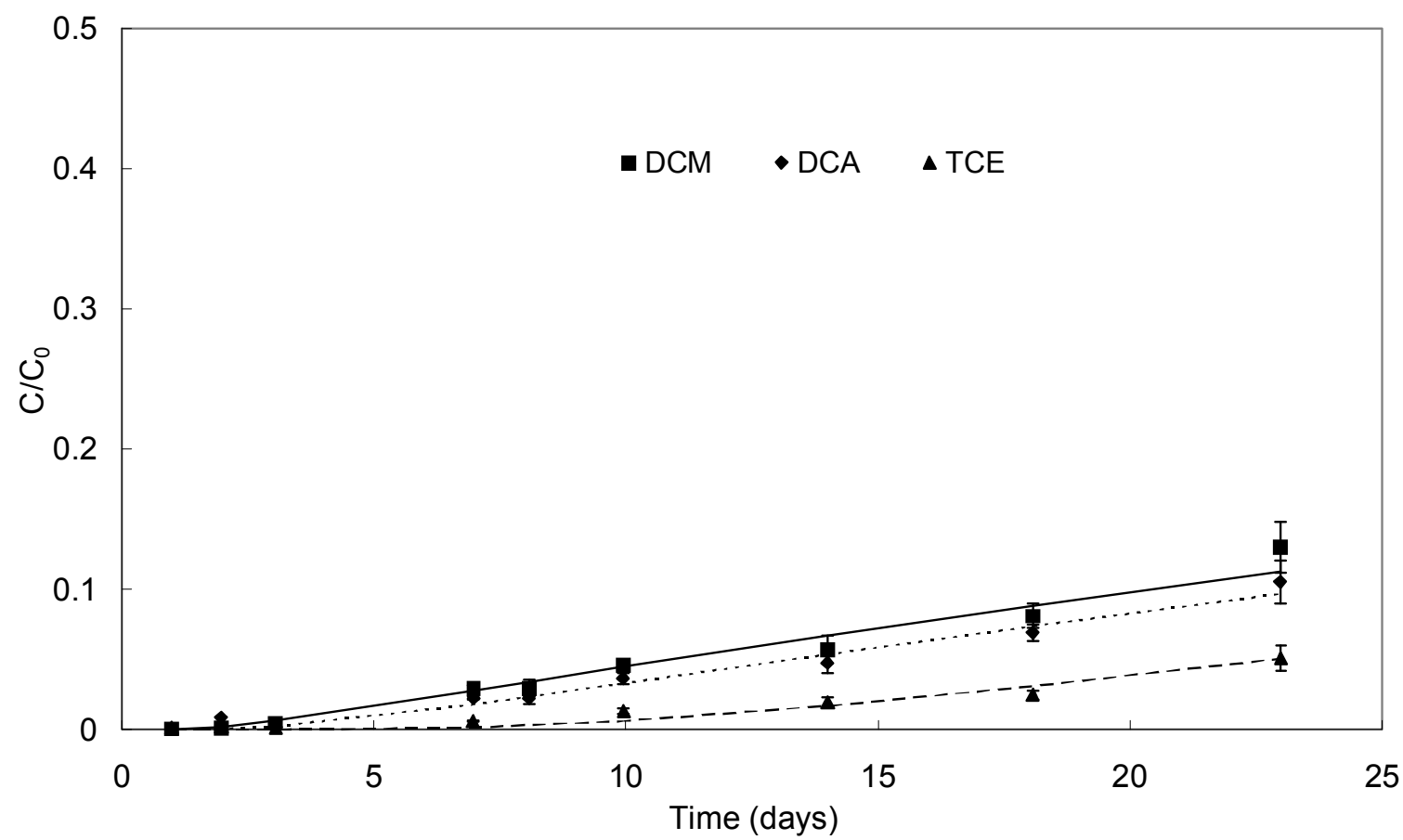

(b)

Fig. 3. Evolution of concentrations of DCM, DCA and TCE at the (a) inlet and (b) outlet of the cell for GCL 1 
Figure 4.pdf

Journal of Geotechnical and Geoenvironmental Engineering. Submitted May 13, 2010; accepted February 11, 2011; posted ahead of print February 14, 2011. doi:10.1061/(ASCE)GT.1943-5606.0000525

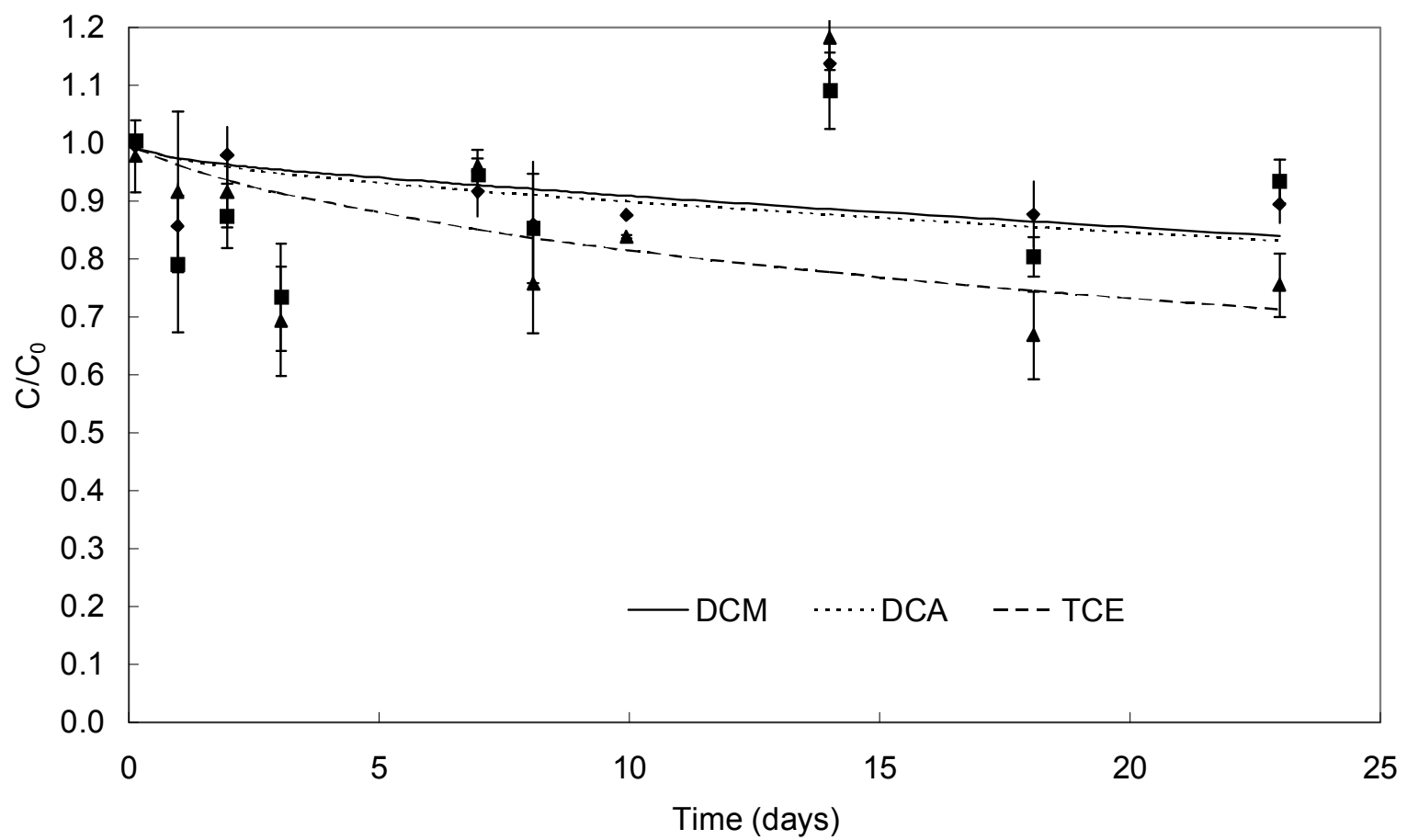

(a)

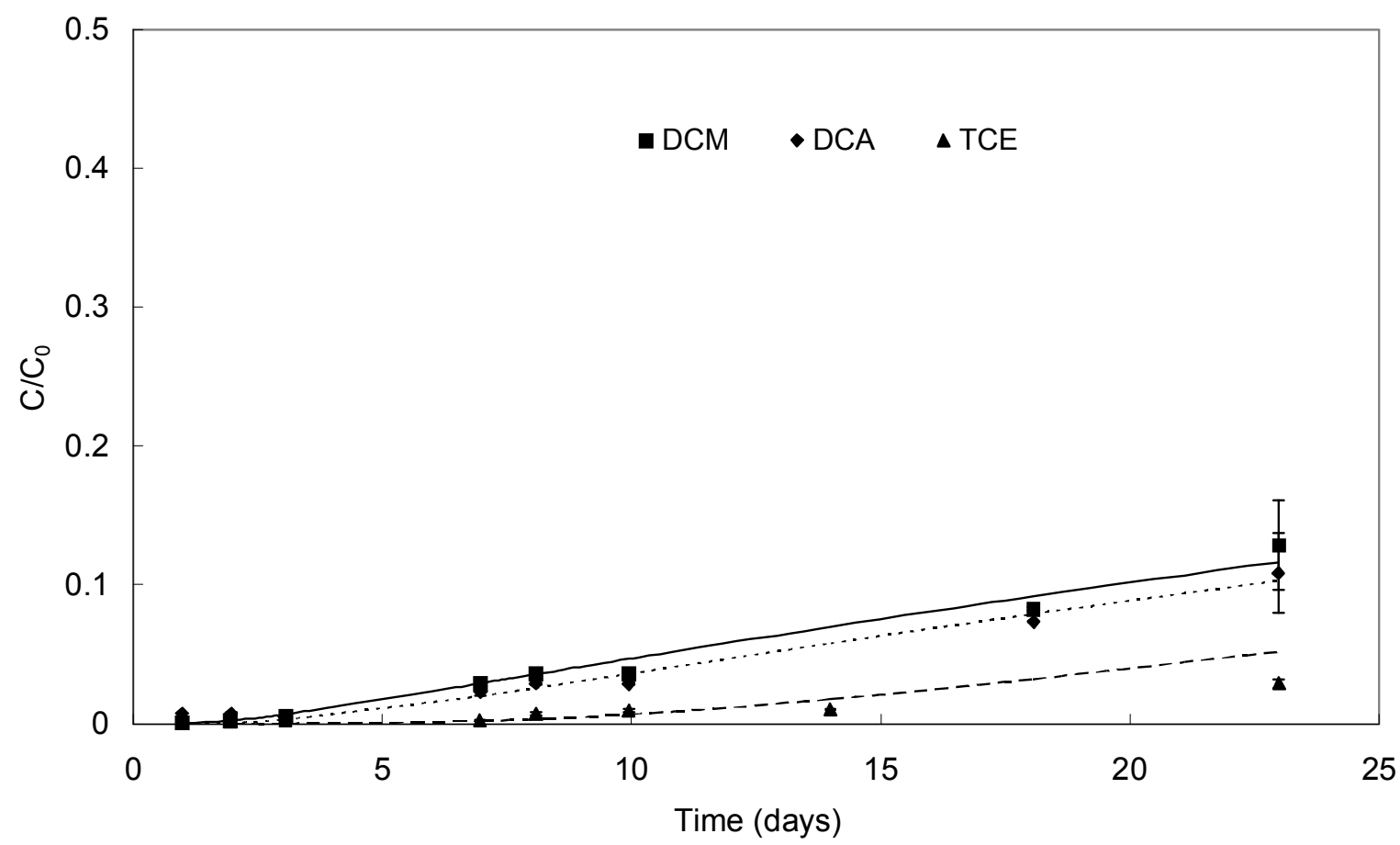

(b)

Fig. 4. Evolution of concentrations of DCM, DCA and TCE at the (a) inlet and (b) outlet of the cell for GCL2 
Figure 5.pdf

Journal of Geotechnical and Geoenvironmental Engineering. Submitted May 13, 2010; accepted February 11, 2011; posted ahead of print February 14, 2011. doi:10.1061/(ASCE)GT.1943-5606.0000525

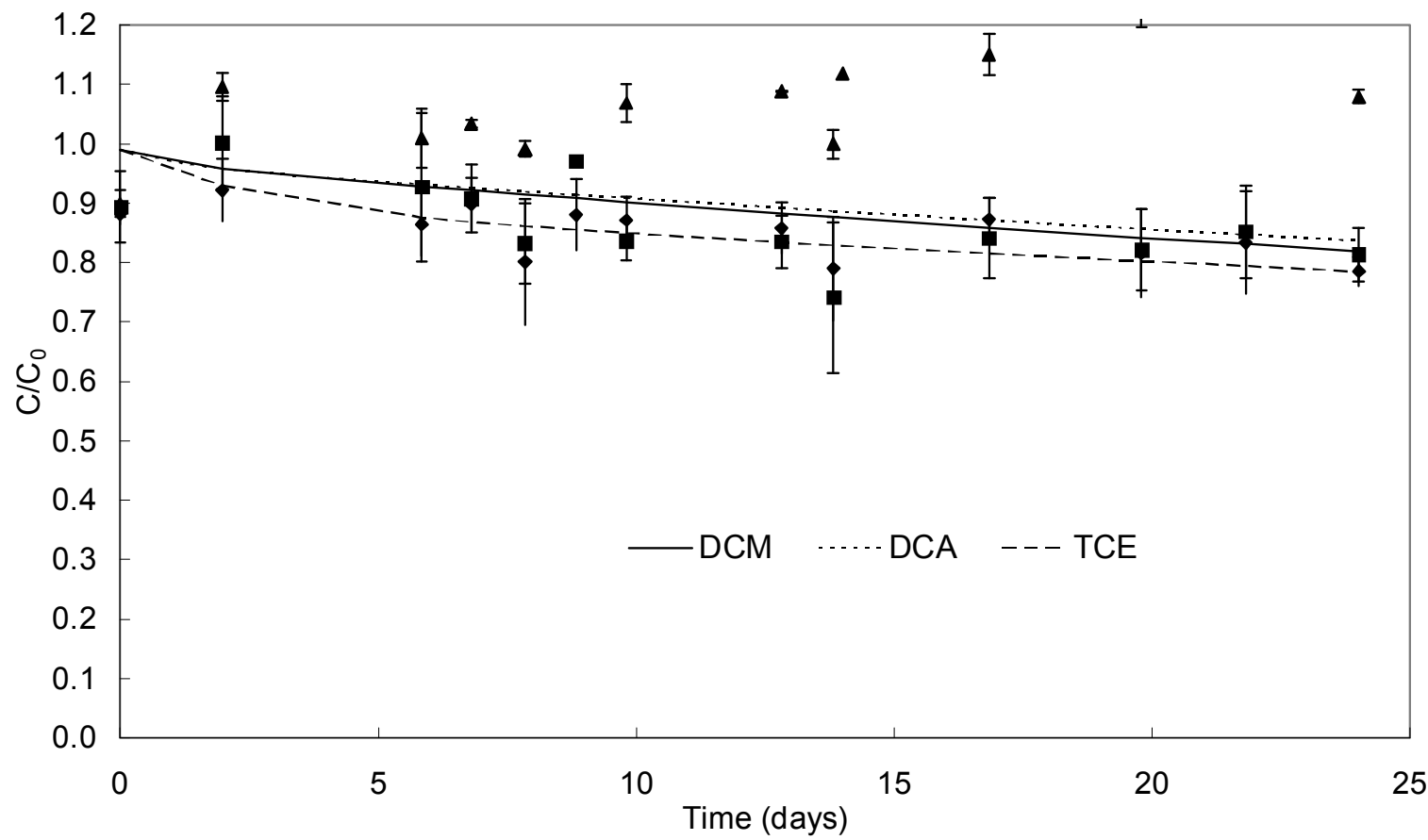

(a)

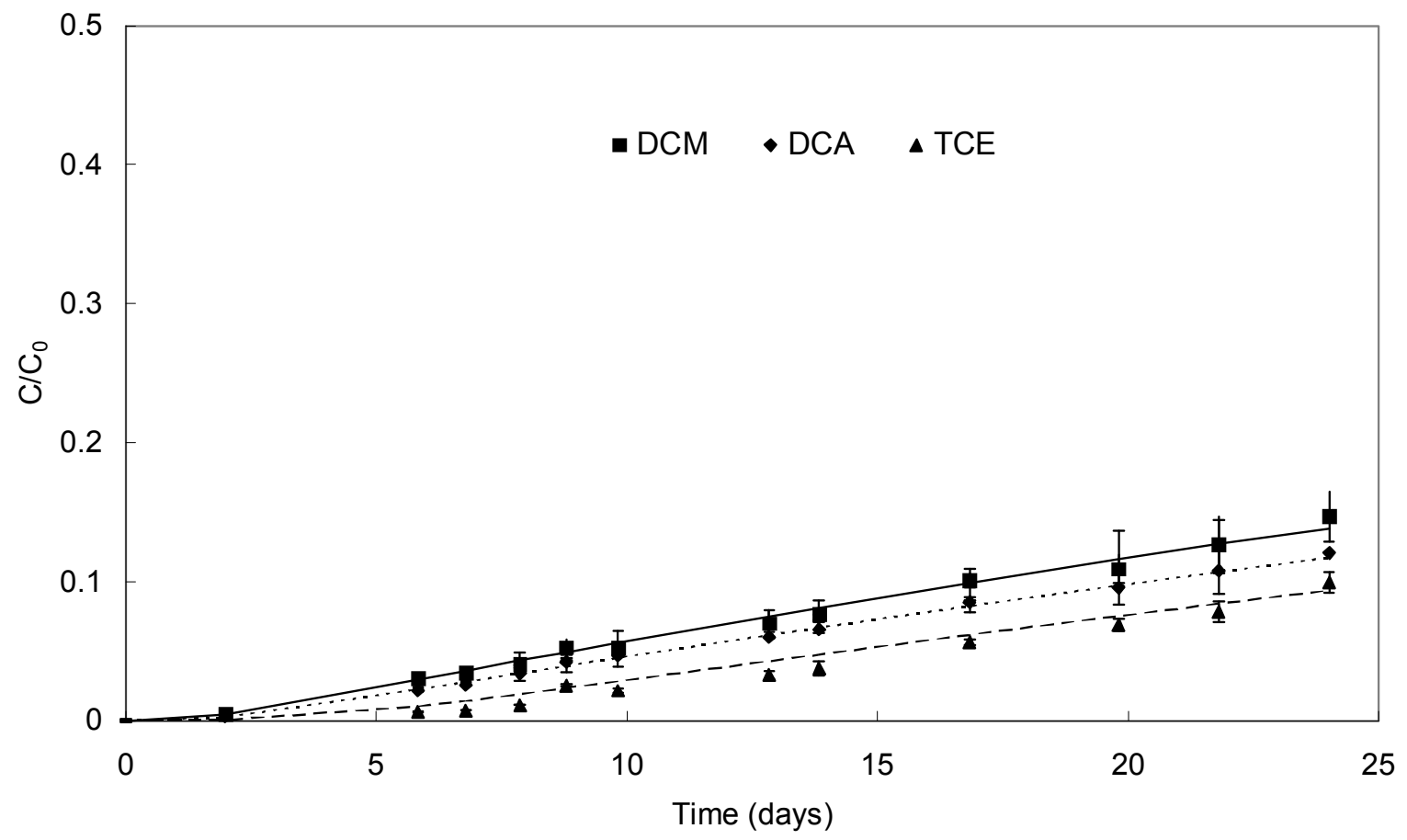

(b)

Fig. 5. Evolution of concentrations of DCM, DCA and TCE at the (a) inlet and (b) outlet of the cell for GCL 1 after cation exchange with $e_{b}$ equal to 3.9 